\author{
DEPARTMENT OF THE INTERIOR \\ UNITED STATES GEOLOGICAL SURVEY
}

PREPARED IN COOPERATION WITH

THE MICHIGAN DEPARTMENT OF CONSERVATION

GEOLOGICAL SURVEY DIVISION

\title{
AEROMAGNETIC MAP OF THE KENTON QUADRANGLE, GOGEBIC ONTONAGON, IRON, AND HOUGHTON COUNTIES, MICHIGAN
}

\author{
GEOPHYSICAL INVESTIGATIONS \\ MAP GP-604
}

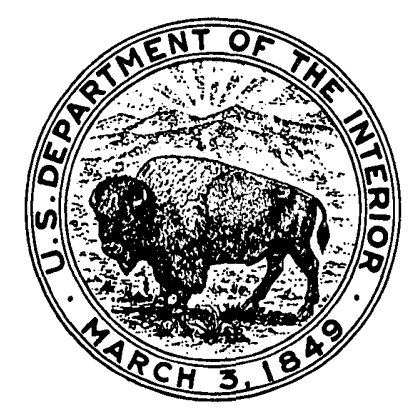

PUBLISHED BY THE U.S. GEOLOGICAL SURVEY WASHINGTON. D. C. 